\title{
Identity and Post-Colonial Discourse: Gene Luen Yang's American Born Chinese
}

Rasha Abd El Rehim El Gohary*

Psychologists and social psychologists have long discussed the process of identity formation and the conflicts associated with it, especially in adolescents. While it was Erik H. Erikson who first set the broad lines for a theoretical framework of ego identity formation, it was James E. Marcia who developed Erikson's work into an identity formation model. Similar specific models were then developed for adolescents from different ethnic minorities with different names for the various developmental stages. For example, Jean Kim and S. Sue and Sue suggested ethnic identity development models for Asian Americans.

Identity is a wide concept that includes several dimensions such as race, gender, sexual orientation, socio-economic class, religion, profession, interests, and roles in life. James E. Marcia operationalized Erikson's two stage egoidentity development into a four-stage model. Marcia speaks first of the identity diffusion subject who does not show any specific commitments in life. He has no ideological or occupational interests. In the foreclosed identity stage, the individual expresses commitment based on his parents' rather than his own choices, so it is a commitment not stemming from any source of self-exploration. The moratorium subject, in contrast, is one who is in a state of crisis, trying to reach a compromise with what his parents want for him, what society demands, and what he is capable of. After going through this stage, the individual realizes an achieved ego-identity. He has a higher self-esteem and a realistic set of expectations (552-57).

While ethnic identity might be more inclusive than racial identity as the latter is marked by distinct physical features and the former includes traditions and cultural heritage (Kim 139; Phinney and Rosenthal 147), this paper will use both interchangeably. Jean Kim came up with a model for the psychological theory of Asian American Racial Identity Development (AARID) that divides ethnic identity formation into five stages: ethnic awareness, white identification, awakening to social political consciousness, redirection to an Asian American consciousness, and finally incorporation (Kim 145). They are quite similar to Marcia's ego identity development and D.W. Sue and Sue's five stage

\footnotetext{
* Assistant Professor of English Language and Literature, Faculty of Al-Alsun and Mass Communication, Misr International University.
} 
Racial/Cultural Identity Development model (R/CID) which consists of five stages: conformity, dissonance, resistance and immersion, introspection, and finally integrative awareness (Sue and Sue 214). The first stage in AARID could be characterized by either a neutral ethnic identity or ethnic pride based on whether these children live in a white neighborhood or an Asian one respectively (Kim 145). This is quite similar to Marcia's foreclosed identity because the individual hasn't really given it much thought yet and just adopts what he is told. If the individual doesn't give it much thought because ethnic identity has no impact on his life, this is similar to Marcia's diffuse ego-identity stage. (Phinney, "Stages of Ethnic Identity" 36-37). The second phase in AARID is similar to conformity in R/CID. It begins with school as Asian Americans are subjected to ridicule by their schoolmates and start to experience "alienation from the self and others", believing that beauty means being white (Kim 146). They "experience periods of wishful thinking and fantasizing about being white". They may begin to "mimic what is perceived as white mannerisms, speech patterns, dress, and goals." They even project the same negative views on other minority groups (Sue and Sue 219-20).

Contrary to this stage, the third stage in AARID and the second and third stages in R/CID are characterized by social and political awareness as they realize that such racism is the responsibility of society and is due to no fault of theirs. They develop feelings of ethnic pride and shame of their past attitude, and they overcome feelings of inferiority as they develop a better self-image, but feelings of anger and hostility towards the White majority arise (Kim 147; Sue and Sue 220-22). They share a sense of political "comradeship" with other minority groups, especially in the third stage in R/CID (Sue and Sue 223). They begin to examine their ethnic identity just like Marcia's moratorium stage. The fourth stage in Kim's model as well as the introspection stage in Sues' model comes as a natural development to this stage. Asian Americans forgo the anger and resentment of the previous stage. They realize that such "intensity of feelings" is "psychologically draining" and does not allow them to really understand themselves any better. They adopt an attitude of "selective trust and distrust" towards different individuals of the majority and realize the similarities between their group and other minority groups (224). Kim adds, however, that they get involved in Asian American culture and live proudly as Americans of Asian descent. By the end of this stage, they have resolved their identity conflict. The last stage in Kim's model is just an extension of this stage characterized by even more self-confidence as the individual merges the racial part of his identity with all the other parts (148). It is similar to Sues' integrative awareness stage where the individual becomes bicultural (Sue and Sue 226). By resolving their identity issues, individuals enter Marcia's achieved identity stage (Phinney, 
"Stages of Ethnic Identity 37-38; Phinney and Rosenthal 150, 161). Kim, however, believes that this is not a one-way ride as the individual can face regression. This is asserted by Phinney in "Ethnic Identity in Adolescents" as she identifies four possible ways of dealing with ethnic identity: biculturalism, marginality, assimilation, and separation, and she states that one does not stay in any of these stages forever as ethnic identity is ever changing (502).

Elsie Smith refers to the intense internal conflicts that the individual experiences on his way to ethnic identity formation. If the individual is faced at an early stage with the dominant group's negative image of his ethnic group or any negative oppressive experience, he may suffer from a split identity in his inability to reconcile his Chinese and American selves, and unconsciously create a 'double' through which he can escape his ethnicity conflict (182-86). The value of the double lies, according to Zivkovic, "in its escapist qualities, in the possibility it offers to the individual to imagine his self and reproduce himself in endless ways" (122). The double, according to Zivkovic, is "a manifestation of unconscious desire ... an externalized part of the self" (125). The conscious mind thus tries to defend itself against feelings of inferiority and self-hatred either by projecting all that it wishes to deny on a real person or by hallucinating and imagining such a person (125). The double could also be created by the White to demonize groups that possess qualities they lack. Otto Rank states in his study of the double that the double represents a person's "desire to depict distinct and separate traits for himself, or ...his desire for another existence" (xi). He says that writers use the theme of the double mainly to investigate the problem of "the relation of the self to the self' (xiv).

Sigmund Freud in his essay on "The Uncanny" specifies the double as a source of the uncanny. He explains the double in more or less the same terms. He says, "a person may identify himself with another and so become unsure of his true self; or he may substitute the other's self for his own. The self may thus be duplicated, divided and interchanged" (142). Rank states that a "powerful consciousness of guilt ... forces the hero no longer to accept the responsibility of certain actions of his ego, but to place it upon another ego, a double" (76). Thus, the ego represses all the wishes, desires, and possibilities. The double is hence "something that has been repressed and now returns" (Freud, "Uncanny" 147). The double is thus familiar to the individual because it is originally part of his psyche, which he repressed, but it is then "ejected from the ego" as a form of defense mechanism "and is treated as something alien" (143). That is why the death of the double is actually the death of the self because the double is a reflection or a projection of the self.

In fact, the whole concept of colonization is based on the same principles. Fanon claims that the white colonizers need to project all their base emotions 
and abhorred traits on someone else in order to escape acknowledging these qualities as actually belonging to them, and thus, it is the Negro and the colonized races who carry "the burden of original sin" and become completely demonized (Black Skin 149). Fanon also states another interlinked reason why the 'other' is so hateful but at the same time so alluring for the 'self'. In an idealized racist reaction, the European colonizer or White majority believes that the 'other' possesses a highly desirable quality that is lacking in the 'self', which gives the White majority a feeling of inadequacy and an attitude of jealousy from the colonized. Derek Hook explains this by saying that the White European craves this quality and "comes to fear and hate it or, more directly, the racial other for possessing it" (130). Both forms of racist reactions toward the 'other' lead to the phenomenon of stereotyping which fabricates the identity of the colonized (Fanon, The Wretched 2; Said 6-7) "into a kind of quintessence of evil" ready to infect anything that comes close to it. The customs and traditions of the colonized become the mark of their depravity. As a result, the colonized is "dehumanized", "reduced to the state of an animal" (Fanon, The Wretched 6-7), "a tertium quid" (Du Bois 67), "a thing" created by God only to serve the mentally and morally superior white race (Césaire, Discourse 41-42) as opposed to the backward uncivilized Orient in Said's terms (6-7). The problem is the negative psychosocial effects that the minority or the 'other' suffers from because of this false fabricated identity.

An inferiority complex develops and is according to Fanon "internalize(ed)" or "epidermaliz(ed)" (Black Skin 4) as the colonized man measures his worth through the scornful look of the eyes of the colonizer (Du Bois 9; Césaire, Discourse 42) He is transformed into an "obsessive neurotic" undergoing a violent internal struggle between his "own sense of self" and an "ascribed self" suffering from "double-consciousness" (Fanon 43; Black 394; Du Bois 9), a "wrenching of the soul" as he has to live "a double life, with double thoughts,... and double ideals" (Du Bois 145). As he awaits rejection at every moment, he becomes envious of the colonizer and dreams of owning everything the colonizer possesses, even his wife. (Fanon, The Wretched 5). The colonized or the oppressed dream first of identifying with their oppressors and then replacing them altogether. This dream may lead to one of two paths: neurosis or violence.

Neurosis is when the colonized, or the oppressed becomes obsessed with the wish to be white, and his "psychic structure is in danger of disintegration" (Fanon, Black Skin 74). Derek Hook clarifies that at one point in this 'racial neurosis', 'I, the black subject, experience myself to be white, I have taken on the subjectivity of whiteness" (127). This wish, however, as Hook states, is impossible to attain as it usually comes in conflict with being trapped inside a 
body with distinct racial features (117) or inside the Duboisian "Veil of Color" (Du Bois 68, 145).

After being physically and psychologically humiliated, anger builds up in the colonized in the form of muscular tension and nightly "muscular dreams" of action and self-assertion (Fanon, The Wretched 15-16). Unable to keep this anger boiling inside him for long and at the same time unable to face his oppressor, the colonized unleashes his anger onto his own brethren (17), thinking "he is destroying once and for all the hated image of their common debasement" (Sartre qtd. in Fanon, The Wretched liii). By killing the double, the person actually desires to get rid of the part of him which he hates or is ashamed of.

Thus, the colonized or the oppressed people have to take the struggle one step further and actually attack the colonizer in their struggle for liberation. While Du Bois speaks of violence as a negative psychological and sociological result of discrimination (145), Fanon believes it is a necessary step towards liberation. Sartre states, "once their rage explodes, they recover their lost coherence, they experience self-knowledge through reconstruction of themselves" (qtd. in Fanon, The Wretched lv). The liberation struggle teaches them the importance of communal ties, brotherly love, and unity. They learn to embrace one another, and they seek to uncover a glorious common past and culture as psychologically balanced individuals (Fanon, The Wretched 148). This stage is quite similar to what Césaire, in an interview with René Depestre, calls "Negritude", a rediscovery of African consciousness, an angry movement against assimilation, a revival of cultural history and pride in black civilization (30).

However, Fanon does realize the importance of embracing one's culture but at the same time seeking to enter the global world, as he advocates a "dual emergence" for third world countries, which is based on "national sovereignty and international solidarity" (Bhabha qtd. in Fanon, The Wretched xxvi). This is exactly what is advocated by Du Bois as he believes that the end of the Negro's mental and cultural struggle is to "merge his double self into a better and truer self" without foregoing either of the two selves. Du Bois claims that the Negro does not desire to Africanize America nor Americanize Africa, for he realizes the importance of both. He just aspires to be able to live as both an American and a Negro (9). In his interview with Depestre, Césaire claims that the African American (or any member of a minority) needs to realize that he bears "the imprint of European civilization", but he also should foster the belief in the contribution that the African civilization could make to Europe (30). This is quite similar to the ethnic minority individual moving from the stage of "resistance and immersion" to the "integrative awareness stage"; that is to say towards realizing achieved ego and racial/ethnic identities. 
Identity issues and racism have always found their way into literature. They appear repetitively in the works of Chinese American writer, Gene Luen Yang (1973). Yang's American Born Chinese (ABC), a graphic novel published in 2006 about Asian American identity isuues, has received five "Best Book of the Year" awards; it weaves three seemingly disconnected and fragmented stories united by the themes of transformation, discrimination, and identity. The first story is a Chinese myth about the Monkey King, a Chinese deity who travels from India to China to bring the principles of Buddhism to China. The second story is a coming of age story of a Chinese American boy, Jin Wang. In an interview with Margolis, Yang admits that this story has autobiographical references to his own school years ("American Born" 41). The third story is written in the style of a sitcom on paper, according to Yang in an interview by Engberg ("Gene Luen" 75). It deals with an American boy called Danny and the troubles he has at school when his stereotypical Chinese cousin Chin-Kee comes to visit him. The connection among the alternating stories becomes clear only at the end when Danny is revealed to be really Jin Wang after having shed off his Chinese identity and embracing an all American identity, and Chin-Kee is revealed to be the Monkey King who comes to teach Danny a lesson about the need to embrace his heritage and his true self, a lesson the former has learnt at an expensive price.

This paper aims to show how racism and stereotyping can lead to an identity dilemma especially among American teenagers of Asian descent. Accordingly, it examines the psycho-social effects of racism on three different characters in the novel by employing the works of post-colonial theorists like Frantz Fanon and psychoanalytic theories of the double and uses the different models of identity development especially those applicable to ethnic identity development to trace the different identity stages these characters pass through on their way to finally achieving a balanced ethnic identity. The paper employs a formal analysis of the graphic novel as a genre by referring to different comics theorists to show how text and image combine to deliver Yang's message about the necessity for Asian Americans to achieve a balance between mainstream and ethnic traits to live a healthy life as stable individuals serving their society.

The medium of writing, the genre of each story in American Born Chinese, and the choice of narrative voice in the different stories serve different purposes. Since graphic novels are a branch of comics, and comics have always been stigmatized and regarded as a form of low culture, Yang's choice of the graphic novel is appropriate to the topic of racism and ensuing shame that is felt by certain ethnic minorities during the stages of their identity development (Oh 21). The genre of each story is also significant. Claudia Schumann states that the use of Eastern and Western style stories emphasizes Yang's message about the 
importance for Asian Americans to reconcile both parts of their identity (44). The Monkey King story is a myth of the collective unconscious acting as a frame that envelops the other two stories as it proves the same point they are trying to state and which the Monkey King voices at the end, "I would have saved myself from five hundred years' imprisonment beneath a mountain of rock had I only realized how good it is to be a monkey" (Yang, $A B C 223$ ). Its narrator is a heterodiegetic omniscient narrator privy to the Monkey King's thoughts. The Monkey King is only permitted to speak up for himself in the last section of the novel when he accepts his true self. Jin himself, a homodiegetic narrator, narrates his own story, as it is a semi-autobiographical bildungsroman. However, the focalizer in the story is Jin before the revelation. Thus, his perceptions and interpretations are deficient because he hasn't reached a mature stable identity. In one instance in the story of Jin just before his transformation (pages 163-164), there is disjunction between the narration on the one hand and the dialogue and pictures on the other hand as if Jin were distancing himself from his true self as he is ready to embrace the imaginary Danny. Moreover, while the narrator is recounting how the Chinese forbid dating at a young age, the dialogue and the pictures show how Jun Wang is contriving to set up a date for himself, which reflects the contradiction between the Chinese and American lifestyles and accordingly the protagonist's dilemma.

The narrator recedes in the background in Danny's story, which is a sitcom, mainly because the readers are aware that they are watching a show through the laughter track and the claps at the bottom of the panels, which makes them doubt the truth of what they are viewing. It reflects the dream world of Jin Wang created by him in an attempt to overcome the ethnic shame that made him into a neurotic desiring to "run away from his own individuality to annihilate his own presence" (Fanon, Black Skin 143). Addressing the reader directly in the narration, such as on page 166 , also poses the novel as a metafiction and thus makes the reader doubt the reality of what he is witnessing as he wishes that Jin and all adolescents doubt the reality of the stereotypes they are bombarded with.

The story of the Monkey King starts with the monkey in Marcia's identity diffusion stage. He self-confidently rules Flower Fruit Mountain. He is actually proud of who he is as he lives in a place inhabited mainly by his own species, which is exactly the same case for an ethnic minority individual who lives in an ethnic neighborhood. As the Monkey King goes to (school) the dinner party where all the other deities are invited, he is treated as an inferior because of his species/race, and he is sneered at by the guard, who supposedly occupies a lower station in life than him. But as is the case with racism, even white people from lower social classes are prejudiced against people of color. This is clear in the facial expression of the guard in the bottom left panel on page 15 as well as the 
fourth panel on the same page where the guests all point their fingers at him laughing, as is clear from the onomatopoeic written sounds " $\mathrm{Ha} \mathrm{Ha} \mathrm{Ha",} \mathrm{which}$ is very humiliating. He is denied admittance to the dinner party because of a physically distinguishing ethnic marker, lack of shoes, which the monstrator emphasizes with a close-up in the top right -hand panel on page 14. The guard, who represents the colonizer, insists, "You may be a King-you may even be a deity-but you are still a monkey" (Yang, $A B C$ 15). This statement stands out as a racial indictment, for as Michael Chaney claims, "the Monkey King operates less as an allegorical animal than as a metaphorical minority" (136), which is the same opinion reiterated by Mike Cadden. Americans have historically used the image of the monkey as a "racial diminutive, a way to picture Asians as subhuman" (Song 85). Seeing himself through the eyes of the White majority, the Monkey King, "embarrassed" (Yang, $A B C$ 15), develops an inferiority complex, desires to annihilate his identity as a monkey, and plans to adopt a White identity.

The Monkey King is thus initiated in the second stage of Kim's AARID model, white identification. He starts to look down on individuals from his same race/species and develop "racial self-hatred". That is why as he starts feeling very self-conscious and ashamed of his simian/ethnic self, he could sense the "thick smell of monkey fur", which previously he was unaware of (Yang, $A B C$ 20). He starts seeing his own group through the lens of the dominant group and is accordingly repulsed by the "stink" and the "odors from the native quarters" (Fanon, The Wretched 6-7). The fact that the party is held up in the sky and that going back home for the Monkey King requires a 'descent' mimics the "compartmentalized world" of the colonizers and colonized where the colonizers enjoy the privileges of living in elite neighborhoods while the colonized live in poor crowded ones (Fanon, The Wretched 4-5). The descent also implies the inferiority of the Monkey King's world in comparison to the world of the deities and spirits. The coloring of the panels, the use of lighting effects, and the positioning of the figure of the Monkey King are all techniques used by the monstrator to highlight the Monkey King's trauma and identity crisis. The two panels on the right on page 20 are completely dark, which reflects the drastic fatal effects of the trauma on the psyche of the Monkey King. The lighting on the floor and the door as opposed to the dark figure of the monkey and the rest of the background creates a sinister air foreboding the process of schizophrenic severing of the identity especially as the shadow of the Monkey is reflected on the floor. The disproportion between the huge dark space surrounding the figure of the monkey in the last panel, which is termed negative space by Ralph Duncan, and the small positive space occupied by the monkey, "accentuates the figure's vulnerability and isolation" (72) as he internalizes the racist remarks 
directed against him by the majority. In an attempt to deal with the internal anger created by oppression, he lashes out against individuals from his own race/species as he issues a decree forcing all monkeys to wear shoes. When offered a banana by his subjects, the monstrator shows how he looks down upon them with disgust as if he has shed all ties with his former self, especially when he states of the scroll that he receives from heaven, "this monkey king it speaks of no longer exists" (Yang, $A B C$ 60). He represents the Colonized elite in their mimicking of the White colonizers as he calls himself "the Great Sage Equal of Heaven", and he teaches himself the four major disciplines of invulnerabilityWhite mannerisms- which can make him stand up to any of the deities/ White people.

Convincing himself that he is a deity, the character suffers from denial and uses this defense mechanism to deal with "psychological dissonance and discomfort" (E. Smith 186). The monstrator cleverly shows this in the first panel on page 60 as he uses a long vertical panel disproportionate to the other panels that contain images of other monkey subjects on the same page. The long vertical panel shows how the Monkey King imitates humans as he stands straight and tall on two feet. This aggrandizement of the figure of the Monkey King reflects that he aspires to be a god. His figure even extends outside the frame of the panel producing what Thierry Groensteen refers to as "the cat-walk effect" (57). The purpose of the cat-walk effect is to show that after developing a high sense of self, the Monkey King can no longer be contained within a panel. The Monkey King, just like the Asian American, suffers from a split identity in his inability to reconcile his Chinese/simian identity and American/ deific identity. He "feels his twoness, ... two souls, two thoughts, two unreconciled strivings; two warring ideals in one ...body" (Du Bois 9). Accordingly, he unconsciously creates a 'double'- Chin-Kee- through which he can escape his ethnicity conflict. It is Tzeyo-Tzuh, the father of the gods, who forces him to explore his identity and enter the moratorium stage or the R/CID's dissonance stage. Tze-yo-Tzuh tells him, "I created you. I say that you are a monkey. Therefore, you are a monkey" (Yang, $A B C$ 69). He has to know that his inferior identity is only a fabricated social construct. As the Monkey King attempts to escape Tze-Yo-Tzuh, he rushes out of the panel frame, and is shown standing in a white frameless page facing five pillars which are really Tze-Yo-Tzuh's five fingers. Although writing his name on one of these pillars might indicate his desire, like the colonized elite, to imitate the White colonizer/majority, urinating over this same pillar is an unconscious expression of his detest of this act of mimicking the White and his unconscious knowledge of the need to accept his true self before developing a unified self. The white space, signifying eternity and timelessness, indicates that no matter how hard the monkey tries, he has to face his ethnicity, his original creation. 
Also, breaking the boundaries of the panel makes the reader identify more with the Monkey King and experience his feelings.

The moratorium stage in Marcia's terms, or awakening to social political consciousness and redirection to an Asian American consciouness in Kim's model, or introspection in Sues' model happens in the five hundred years the Monkey King spends trapped under a mountain rock thinking. Literally and symbolically, his physical and psychological getaway comes from his transformation back to his true self, from his acceptance of his ethnic identity and finally realizing a balanced identity. Wong Lai-Tsao, the monk, tells him, "To find your true identity ... within the will of Tze-Yo-Tzuh ...That is the highest of all freedoms" (Yang, $A B C$ 149). He accepts both parts of his identity as he takes off his shoes and uses natural monkey instincts-emitting gas- and more advanced human Kung-fu skills to save the monk. Only when he reaches self-acceptance does he reach his full potential, and accordingly Tze-Yo-Tzuh raises him to the status of an emissary. It is significant that in the adaptation of the story of Monkey King, Journey to the West, Yang gives the story a JudeoChristian spirit as it bears semblance to the story of the three Magi who bring three gifts to baby Jesus, signified by the shining star which the Monkey King and the monk Lai-Tsao walk toward (P. Smith 8) and the portrayal of the Virgin Mary and baby Jesus extending his hand to the Monkey King (Young, $A B C 215$ ). Thus, it is apparent that Yang merges Chinese and Christian beliefs to highlight the very composition of a balanced Asian American identity.

The Bildungsroman of Jin Wang echoes the same story of the Monkey King. Jin Wang starts out "un-self-conscious" (Sarigianides 41) about his ethnic identity and the meaning it holds; hence, he is in Marcia's diffused identity stage as he lives near Chinatown among Asian friends conversing in Chinese as is clear from putting the spoken words uttered by the boys between angle brackets on page 26 to show that this is just an English translation. However, the panel in the lower right corner on page 25 foreshadows, according to Sheng-Mei Ma, the identity dilemma the character will soon experience as the reader sees baby Jin looking out of the window of his apartment to Chinatown store signs written in Chinese, but the television antenna on the right hand in the panel is pointing towards a McDonald's sign with the letter $M$ visible in the image. Since McDonald's symbolizes one of American culture's significant markers, fast food chains, the appearance of the sign and of the television in the image "commences an Americanization" but the baby looking out at the yang sign highlights that there is still hope of a "homecoming" for Jin Wang (110). It is noteworthy that it seems that Jin's parents could be a reason for his upcoming dilemma, for though they talk to him in Chinese, they decide to move to a white neighborhood and send him to an all-White school, the purpose of which according to the 
parents is to give him a good education so that he can live up to the model minority stereotype. Jin concludes this from the Chinese parable his mother narrates called "The Three Moves of Mencius' Mother", which is about Mencius, Confucius' disciple who is taught to value learning (Yang, $A B C$ 2324). However, Jin's mother does not narrate the story in the exact same order as the original (Ma 108), which could show either a distortion of Chinese past as the parents themselves seem unable to convey to Jin an authentic Chinese heritage or the parents' desire for Jin to make use of the best of both worlds. Moreover, when Jin moves to an all-White school, he starts to feel the inferiority of his ethnicity. He is subjected to many racist acts from teachers and students alike ranging from mispronouncing his name; to making fun of his Chinese culinary habits as some students accuse him of eating dogs, a common misconception spread by American media; to calling him "bucktooth" (Yang, $A B C$ 33), a derogatory remark hurled at Asian Americans. To finally warn him to break off his relationship with the White American Amelia as a result of racist White rejection of interracial marriage. In an Interview with Heeseung Kim, Gene Yang admits that some of the pejorative remarks spoken by Timmy in the novel were directed at him in junior high school ("Talking" N6). Sarigianides states that all these are just common misconceptions propagated by the America media and contributing to Asian Americans' devaluation of their ethnic identity (42).

Moving from the safe haven of his Asian community and facing racism, Jin Wang suffers from an identity crisis just like his creator or in other words becomes "abnormal" and develops neurosis (Fanon, Black Skin 111). Jin develops a deep sense of shame and racial self-hatred. His loneliness is clear in the panel composition. On page 32, the first long horizontal panel is divided into three gutterless macropanels, depicting the different simultaneous activities other American children are involved in at school, suggesting how these children are enjoying themselves without sensing the passing of time. This image is directly juxtaposed with the subsequent image that is almost repeated two more times on page 35 and 179 with slight variations in seasons and the age of Wang. The reader would have to rely on braiding, one of the structural devices of comics, which forces the reader to opt not just for a linear reading of comics but to make bridges between different corresponding moments throughout the narrative (Groensteen 122). The repeated image in this case is a long horizontal panel of Wang, smaller in size than any other figure, sitting all alone in the right corner of the horizontal panel with the rest of the empty bench occupying the rest of the panel and a grey background. This serves to reiterate the long-time alienation of Jin Wang on account of his racial features and his sense of inadequacy. Moreover, since comics are supposed to be read from left to right, 
according to McCloud (Making Comics 32), the reader's eye would have to move for some time till it reaches the figure of Jin Wang on the other side of the panel, which gives the reader a sense of Jin Wang's isolation. Ralph Duncan claims that "When a main visual element is placed outside the balance of the felt axis the element itself is more noticeable, and a greater sense of stress is created in the panel" (74). Accordingly, placing the main figure on the right side of the panel rather than the left or even the center creates a feeling of tension that mimics the internal turmoil the character is experiencing. The reader senses the disturbance to the normal order of the panel composition, which reflects a disturbance in Wang's sense of identity. This composition also serves to accentuate the character's marginalized position, as according to McCloud, readers only assign importance to figures that appear in the center of the panel (Making Comics 24). In addition, the long horizontal panel actually serves to increase the duration of the moment presented in this panel (McCloud, Understanding Comics 101). Hence, it emphasizes Jin Wang's loneliness and shows that it has not been a one moment thing for him. His self-consciousness is also clear when Greg tells him to stay away from the white Amelia. He is shown as the only colored figure sitting in the right bottom panel on page 181 with a dejected look in a sepia and black class, which marks him out from the majority.

Jin Wang identifies internally with his white aggressor and harbors the dream of literally becoming white. Derek Hook further explains this when he states that "racial neurosis" does not just mean "racial alienation" but that a person's race becomes "objectified" for him so that he understands his race only through a white lens (127). That is why Jin Wang, projecting Greg's racist remarks about interracial marriage on the Taiwanese Wei-Chen, yells at him calling him an "F.O.B", a racist slur that means fresh-off-the boat and tells him, "I just don't think you're right for her...I think she can do better than an F.O.B like you" (Yang, $A B C$ 191). Just like the colonized person becomes full at first of selfloathing, Jin Wang becomes full of anger. He deals with his pent up anger in two ways before he embarks on the liberation stage. He unleashes his muscular tension, like the typical colonized, in daydreams as he fantasizes about standing up to Greg and even punching him in the face. While the traditional balloon color is white, any change in this color is considered by Groensteen "a carrier of information" (62). Colors, in general, and colored balloons, in particular, express characters' emotions and create a certain ambience (Forceville et al. 61) This depends on the color saturation as well as the choice of cool or warm colors (Painter et al. 35). The monstrator uses the cloud-shaped balloon with a grey background on page 182 to relay Wang's gloominess to the reader and to reveal that Wang is becoming detached from reality as he imagines ways of dealing 
with Greg. The second way for dealing with this anger, after having adopted the colonizer's view of himself, is by directing it against his own brethren, against his own race, trying to destroy the hateful image he has absorbed about himself. That is why he violates the honor of Wei-Chen by kissing his Japanese-American girlfriend since he does not dare kiss the White Amelia, and he does not even apologize but attacks Wei-Chen verbally.

Unable to use violence against the colonizer or the White majority, Jin Wang develops a neurosis. The hero, suffering from the condition of the "white mask psychology" (Hook 133), desires to shed off his racial markers and mimic the white oppressor in different arenas in life. He has to take up "the mother country's cultural standards" in order to be "elevated above his jungle status" (Fanon, Black Skin 9). He enters Sue and Sue's conformity stage. Gene Yang states, in an interview with Heeseung Kim, "I also began to distance myself from my parents and my ethnicity as a way of trying to fit in" ("Talking" N6). In his White Identification stage, according to Kim's AARID model, Jin Wang refuses sometimes to speak Chinese. Fanon calls adopting a language different from the language of one's parents "a dislocation, a separation" (Black Skin 14), as one becomes separated from one's ethnic group. Second, Jin Wang desires to possess the White American Amelia as is clear from the wavy thought balloons with a pink background on page 177 to show that possessing a white woman constitutes a rosy dream for a man from an ethnic minority.

Third, Jin Wang changes his hair style and perms it in an act of self-erasure to imitate the American kid Greg and to shed off one of his Chinese markers, straight hair. Michael D. Boatright and Melissa Schieble respectively deem this a symbolic act of white identification $(473 ; 211)$. To prove this, Schieble highlights the pivotal importance of the frames on page 97 (211). The monstrator shows a long shot of Jin entering his house with a big thought balloon that contains the iconic pictogram of Greg's curly blond hair symbolizing his desire to embrace whiteness. The next panels directly show Jin with the curly hair. It is as if this curly hair gives him the confidence to speak up and ask Amelia out on a date, as is clear from the visual icon of lightning bolts that are emitted from his hair (Yang, $A B C$ 105), which Groensteen calls emanata, graphic signs that convey a character's emotions or physical state (124) and Forceville et al call pictorial runes (62). When Ameila responds with a "yes", the monstrator decides to use it as a sound that bleeds out of the panel on page 105 in big yellow letters in a vertical line both to amplify the echo of the sound to reflect how Jin could not believe himself, naturally because of his sense of inadequacy and to show that for the first time in a long while he experiences hope and energy, notably after he has changed his hairstyle. 
Jin Wang reaches the peak of his self-disavowal when the reader realizes at the end that Jin is actually Danny from the third storyline. Racism is based on Manichean thinking where everything, including racial groups, is 'split' into good and evil, leading eventually to a psychic splitting on the individual level, which is embodied in a double. In literature, this could appear in the form of separate, opposed, or complementary characters that represent "different aspects of a sundered self" (Zivkovic 122), which is what happens in American Born Chinese. Jin Wang makes his Chinese self-invisible by masking or disguising it in order to assimilate and blend in with the dominant group (Davis, "Childhood" 10). Wang projects his deep desire to possess what he thinks he lacks but covets onto an 'other', the white American Danny, who becomes 'a psychic projection of Jin Wang's ideal self' (Chaney 136). Sarigianides believes that this transformation is just an act of suicide, as Jin is actually eradicating a main part of his identity (44).

The transformation of Jin into Danny is actually one of the novel's climactic scenes highly emphasized by the monstrator. The climactic scene is a natural outcome of the repeated strikes that Wei-Chen delivers to Jin's face. The monstrator makes them visible markers on his face in the panels on page 192 to visually externalize his internal conflict in dealing with his ethnic identity (P. Smith 8-9). The splash panel on page 193, the black background, and the words in bold juxtapose this panel with the traditional 2X2 structure with colored background to attract the attention of the reader (qtd. in Hammond 27). The curved edges of the frame, according to Ralph Duncan, make the frame function as a visual sign conveying the feeling that this is an emotionally explosive panel or a violent dream (68), especially since it seems like an antique frame of an old picture; thus, it evokes a childhood memory that could be a turning point in the adolescent's life. The extended claw-like hand of the old Chinese herbalist woman, associating the woman with Chin-Kee, appears to breach the upper border of the frame to indicate that Jin can't really escape his past heritage represented by the hand of the old Chinese woman and to foreshadow that Jin will eventually revert to his former self. In the panel, the woman asks him what he would like to become and immediately, at the bottom of the splash panel on page 194, the reader views multiple images of Jin with his hair and eyes becoming lighter till Danny appears in the last image. The left corner panel on page 195 shows Jin/Danny in the bathroom after waking up from this dream. The side lighting in the bottom panel with Danny's figure half in the light, half in the shadow denotes a split personality, or a morally ambiguous character (Duncan 110), or a character in a moment of internal conflict or "ambiguity" stemming from the conflict of two opposing forces (Forceville and Renckens 175), in this case Chinese and American loyalties. The lighting effects are thus 
used by the monstrator to give depth to the moment and to mimic the split personality that is about to be physically materialized in the form of Jin/Danny. The next three pages are all splash one page panels showing Danny staring at the mirror. Since this takes place in three pages, this reiterates the main theme of transformation that serves as a structural link uniting the three stories. The gaze in the mirror is also important because the mirror reflects the self. It usually reflects the double or one's twin soul, and it reflects a narcissistic but destructive love of the self as Jin now appears to be pleased with his new looks although this new image actually means the destruction and psychological death of his Chinese identity/Jin, for according to the herbalist's wife, "It's easy to become anything you wish so long as you're willing to forfeit your soul" (Yang $A B C 29$ ).

Since transformation in the novel is represented by a toy robot, which Jin Wang and Wei-Chen play with as children, and The Transformers cartoon, which appears several times on TV in the novel, it becomes clear that any transformation is going to be merely fantastical and will not solve the identity conflict of the character. Therefore, for the member of an ethnic minority to reach an achieved ethnic identity and move on to Fanon's liberation stage, he has to let go of childhood fantasies, face and examine his/her fears and conflicts, and transcend this implausible need to transform into a member of the dominant group. Philip Smith remarks that the transformer robots function as another symbol as well. Since the toys were originally designed by the American company Hasbro and the Japanese company Takar Tomy, the toys are "biracial" (9). Thus, they foreshadow the realized hybrid Chinese American identity of Jin Wang.

White identification or complete assimilation is not the solution for ethnic identity dilemma as mainstream perceptions of racial differences will never allow Asian Americans to completely assimilate (Sarigianides 47). That's why Danny tells a school friend that every year he needs to change schools because something goes wrong, and other students start bullying him. Accordingly, Yang forces Wang to enter the following stage of Kim's AARID model, which is developing a social political consciousness, or Marcia's moratorium stage or Fanon's liberation stage, or Sue and Sue's resistance and immersion by having him explore his ethnic identity and come face to face with it rather than escape it. For Jin to be able to do that, Yang creates the character of Chin-Kee, Danny's Chinese cousin who comes to visit him every year from China. Chin-Kee, who according to $\mathrm{Fu}$ is "a deluxe combo of the worst racial stereotypes" (274), reveals to Jin by the end of the novel that he comes every year to serve "as your conscience-as a signpost to your soul" (Yang, $A B C 221$ ), to teach Wang racial pride. It is as if he acts as Jin's superego, the ego ideal which, according to Freud, "answers in every way to what is expected of the higher nature of man". It takes 
the form of conscience implanted in the individual by figures of moral authority (The Ego and the Id 49). Thus, Yang creates Chin-Kee to punish Wang for what Min Song calls a "lack of conscience" in severing one half of his identity (83). The name Chin-Kee, although a racial slur, is also significant if it is pronounced in Chinese as it is a combination of "blood relative" and "key" (Smith 8; Doughty 56). Thus, the literal and metaphorical blood ties between Chin-Kee and Danny/ Jin are undeniable as well as the fact the Chin-Kee functions as the key to unlocking Danny's true self. Chin-Kee pronounces Danny as Dan-nee which means "big you" or "strike you", which could mean, in Doughty's point of view, that Chin-Kee is the opposite Other of Danny's Big White American Self and that it is through punching and striking Danny that Danny will be forced to confront his identity crisis (56).

Chin-Kee, according to Yang in an interview with Rick Margolis, is a controversial character whom some Asian Americans have been displeased with ("American Born" 41). He is an embodiment of both the good and bad stereotypes of Asian Americans (Wang 227). Chin-Kee, "a brutal and ugly caricature" (Gomes and Carter 72), is introduced for the first time in a big splash panel with squinty eyes, buckteeth, a queue, and yellow skin. He speaks Pidgin English, covets American women, and eats strange foods. By answering all the teachers' questions like the model minority, Chin-Kee represents the coveted qualities that the 'self' lacks but desires to possess so it exaggerates such unrealizable qualities and demonizes them in the 'other' that possesses them. According to Gardner, American students' jealousy of the model Asian American students like Chin-Kee, makes them exaggerate the positive stereotype eventually demonizing it and imagining Asian Americans as aliens coming to usurp their places in universities and in the work field (134). Unlike the simple Disney realistic style Yang uses for all his characters, he portrays Chin-Kee in an exaggerated cartoonish form, his body - "shorter, rounder, and somehow disproportionately larger than other figures" (Davis, "Childhood" 12).

Moreover, in a number of panels on pages 48, 49, 203,207,208, 209, 210, Yang draws Chin-Kee larger than reality and taking up most of the space in the panel to overstate the stereotype and make it more visible to force Jin Wang to face the negative image about himself from which he has been hiding (Davis, "American Born Chinese" 280) and to show how destructive this stereotype is on the psyche of the young Asian Americans. This is particularly emphasized when in one of the splash panels, Chin-Kee is seen standing on a table in the cafeteria singing, "She Bang", imitating the exaggerated moves made by William Hung, a Hong Kong born Engineering student who sang the same song on American Idol in 2004. Commenting on the reaction to Hung's performance, Randy Henderson claims, "People are not laughing with Hung, people are 
laughing at him, and the whole entertainment industry seems to be supporting this collective racist guffaw." By presenting it as a sitcom in one splash panel with the exaggerated image of Chin-Kee and his mispronunciation of the words of the song as well as the iconic sound of laughter "Ha Ha" at the bottom of the panel, Yang is actually presenting a dark comedy trying to make the audience conscious of the real reason for their laughter and thus feel ashamed of acquiescing to such racism.

Ashamed of Chin-Kee and unconsciously ashamed of his hidden Chinese self, Danny attempts to escape Chin-Kee by sending him away, which symbolizes his desire to escape his true-self, his inability to confront racism, and his unwillingness to admit that he is actually Jin in disguise. Chin-Kee tells him, however, he cannot leave yet, and he asserts in bold letters with a grin as the camera zooms in in a close-up shot on his face, "Chin-Kee rive for Amellica. Chin-Kee come visit evely year ... Forever" (Yang, $A B C$ 211), which symbolizes the fact that there is no escape for Danny because simply he can't escape from himself, from his roots. The reader does not realize that this is because Chin-Kee is Danny's double as there is also a physical similarity that Amelia points out; he is part of him, and so he can't get rid of him. It is significant that Danny's shadow appears on the wall in the panels on page 127 when he is complaining about Chin-Kee to show the importance of the shadow-the doubleas a recurrent motif in the novel. Jonathan Doughty states, "Chin-Kee, then, functions as a return... of Jin's repressed Asian stereotypes about himself. Of course, "Danny" and "Chin-Kee"are later exposed as alter-egos of Jin Wang, the former his idealized American self, and the other his self-consciousness of being Asian" (57). The monstrator chooses to dress Wei-Chen, the Monkey King, Danny/Jin in secondary colors-orange, violet, and shades of green successively ("Understanding Formal Analysis"). The secondary colors are used to show that all these characters could be a secondary self to the main character Jin.

Yang wants to show that only by confronting such racist stereotypes and accepting what Chin-Kee was created to remind him of-his Chineseness can Jin/Danny "successfully transcend (by symbolically beheading) the stereotype and accept himself" (Davis, "Childhood" 14), an idea reiterated by Sarigianides (47). The physical confrontation before Wang enters the next stage of development is actually a confrontation between "Jin's two self-images": the "racist stereotypes of Chinese identity" and his "imagined identity" (Schumann 49). This physical fight is shown by the swift successive diagonal panels which indicate violence and struggle. The panel that shows Danny striking and beheading Chin-Kee takes up three quarters of page 212 with the head bouncing on the ground taking up the remaining quarter. The background of the panel is black, and all the words are large and bold with the onomatopoeic "pop" 
indicating surprise, written in yellow. The monstrator decides to vary the style of this panel to indicate a climactic moment, which actually functions as the novel's punch line. The marks left by the beatings on Chin-Kee's face before his transformation into the Monkey King are similar to those on Jin's face after his beating by Wei-Chen. They both serve to initiate a transformation; the latter initiates the transformation of Jin into Danny and the former the transformation of Chin-Kee into his true self, the Monley King as well as Danny's reverse transformation and the reemergence of Jin Wang as a complete self. By confronting the racist stereotype propagated in the American media, Jin/Danny is finally able to start calmly examining his cultural heritage in what Sue and Sue describe as the introspection stage before finally reaching an achieved identity.

Danny, thus, reverts to his true self, Jin. Jin finally learns the lesson that the Monkey King has been trying to teach him all along- the need for selfacceptance. The Monkey King sums up the situation as he tells Jin, "I would have saved myself from five hundred years' imprisonment beneath a mountain of rock had I only realized how good it is to be a monkey" (Yang, ABC 223). The panels in this section highlight Jin and the Monkey King sitting all alone on the pavement at night with a sky full of stars. Thus, instead of the black background, the background here has white spots that represent the stars. Obviously, the sky is pure, and the atmosphere is serene in contrast to the violence in the previous scene to allow Jin, who is now in Sues' introspection stage, to contemplate and think deeply about the lesson he has just learnt from the Monkey King and to show that only when Jin is ready to accept himself and to face the racist stereotypes can he achieve serenity. The rest of the panels give a close middle shot of Jin's face to indicate that he is at a time of thinking and decision-making in his life. The positions of the Monkey King on the left-hand side and Jin on the right-hand side in the panels on page 222 indicate the dominant position of the Monkey King and the power he has over Jin at that moment, which foreshadows Jin's succumbing to the lesson delivered by the Monkey King, for according to Karin Kukkonen, the character on the left in the panel has more power than the one on the right because of the direction of reading comics from left to right (8). Jin is then ready to move on to the final stage of the R/CID model which is integrative awareness and the final stages of Kim's AARID model: redirection to an Asian American consciousness and incorporation.

His final development is clear in two instances. For the first time in the novel, as Jin feels at home with his Chinese roots, the reader is given a full picture of Jin's Chinese parents who were previously drawn off frame or from the side. The dialogue between the parents is spoken in Chinese as is clear from the angle brackets on page 225. Second, when he seeks out his old school friend Wei- 
Chen at an Asian café, Jin is actually socializing now with people from his own group. The person who has gone through the process of political and cultural awareness and finally achieves integration usually develops a more positive attitude towards individuals from other minorities in contrast to a more inferior look in his stage of white identification. As Jin's identity develops, Jin's knowledge of Chinese improves. Jin's ignorance of Chinese dialects is clear at the beginning of his visits to the café as he is unable to read the menu, and then as time passes and he becomes even more confident of his Chinese self, the reader notices that Jin has no further problem reading the menu. Meeting WeiChen at a café that has an English and Chinese name is indicative of the reconciliation of both sides of his dual identity. To stress that Jin has successfully merged his Chinese and American identities, the monstrator resorts to an establishing shot on page 233 displaying the café from the outside with the name written in big Chinese letters and the two friends are shown laughing through the window; the purpose of the establishing shot is usually to show the importance of the setting (McCloud, Making Comics 23) while the laugh on Jin's face hints at the reconciliation.

The themes of racism, identity, and transformation are thus the main core of American Born Chinese, depicted through the character of Jin Wang and his doubles. Wei-Chen's character is also another character that undergoes transformation. Although Wei-Chen is subjected to the same racism that Jin encounters, he seems able to cope much better than Jin. He befriends Jin and Suzy, speaks Chinese, and talks comfortably to Amelia unlike Jin. He even tells Jin, "We're brothers, Jin. We're blood" (ABC 190). Thus, Wei-Chen starts out as being comfortable with his Asian identity and mainly intermingling with people from his own group. At the beginning, he is in the first stage of Kim's model or in Marcia's foreclosed identity stage, mainly because he has not yet experienced a crisis that pushes him to investigate his identity. He is what others, most probably his parents, have meant him to be, and this is clear as the reader learns at the end that Wei-Chen is the Monkey King's son and keeps with him a Transformer robot given to him by his father to remind him of his roots. WeiChen, together with Suzy and Jin, is faced at school by racial slurs as "chink" and "gook" ( $A B C$ 96). The damaging effect of racism is at once clear in the last panel on the same page when the monstrator draws the three characters with three stripes like a zebra on each of their cheeks. Nevertheless, it is when Jin Wang, from the same underprivileged position, turns on him, betrays him, and racially insults him, that Wei-Chen is pushed into another stage of his ethnic identity development.

Critics have disagreed about which stage of identity development Wei-Chen moves into. He wears large eyeglasses, earrings, a necklace, holds a cigarette, 
and his hair has an oily, sticky look- which makes him "all surface and emotional hardness" (Song 90). Philip Smith believes that this is Taiwanese gang style dressing adopted by adolescents stressing their Taiwanese roots.; other critics believe this look is like American hip hop style- originally established by the black subculture (10). In either case, it emphasizes Wei-Chen's movement to Kim's stage of awakening to social political consciousness/ Sue and Sue's resistance and immersion stage where he becomes totally involved in his ethnic/minority culture and becomes resentful towards the culture of the majority, refusing even to speak English as is clear from the angle brackets in which his words are inserted in the last couple of pages. When he comes face to face with Jin who tells him he has met his father, the Monkey King, the mask immediately falls off and his true monkey self is revealed in a sepia image, forcing him to face this racial 'othering' instead of attempting to escape it. This panel of the monkey on page 229 might "encode either character's image ... serv(ing) to mediate Jin Wang and Wei-Chen as doubles of each other" (Chaney 137). It also reflects that they can never let go of their true selves and be completely assimilated in American society, simply because their racial birthmarks will always haunt them. They will have to deal with this 'double consciousness', mitigate racism, and accommodate the different parts of their identity. The last scene in which Wei-Chen is seen talking to Jin Wang in a friendly way-although Jin Wang is one of the major reasons for his anger at White culture- may indicate that he is ready to transcend this stage of anger and resentment and move on to the calmer stage of introspection.

American Born Chinese, a post-modern novel, encompasses a number of cultural allusions that Yang skillfully employs to deliver his message. American Born Chinese combines Chinese legend and American pop culture through the story of the Monkey King, which is based on the $16^{\text {th }}$ century Chinese Journey to the West, and the sitcom of Danny and Chin-Kee, which is inspired by the style of the American sitcom 'The Odd Couple' (Chaney 135). The blending of Chinese and American texts solidifies the main theme of the text and the achieved identity that Jin achieves by the end of the novel. There are also two other popular references: the first one, according to Schieble, is a YouTube video, called "Asian Backstreet Boys: I Want it that Way," containing two Asian-American boys singing the Backstreet Boy's song (213), and the second is the Hong-Kong born Engineering student William Hung's performance of the song "She Bang" on American Idol in 2004 (Davis, "Childhood" 13). They are both English songs sung by Asian Americans, so they represent the fusion of Asian and English identities. The Backstreet Video could actually be a challenging to the stereotype, for the two Asians are represented as interested in singing and sports (as they are wearing Jersey shirts), which are typical 
American behaviors, and computing, which Asians excel at. Thus, they are promoting the idea that you can be American but in your own Asian way; you don't have to conform to particular standards; it is a pluralistic society. The last image of Jin Wang and Wei-Chen is presented this time in a hybrid frame, that is a frame which is partly taken from reality (Groensteen 61)- a TV screen, it reminds the reader that what he is witnessing is not reality but a hyperreality that needs to be questioned. Thus, not every image presented about Asian Americans should be believed; it should be analyzed and thoroughly scrutinized and that is the message that Yang is trying to deliver to a whole generation of Asian American adolescents.

\section{Works Cited}

"Asian Backstreet Boys: I Want it that Way. China Kids." YouTube, uploaded by Josh Connelly, 2 Feb. 2008, www.youtube.com/ watch?v=ktqdRbLu804. Accessed 15 July 2014.

Black, Marc. "Fanon and DuBoisian Double Consciousness." Spec. DoubleIssue of Human Architecture: Journal of the Sociology of Self-Knowledge, vol. V, Summer 2007, pp. 393-404. Ebscohost, scholarworks.umb.edu/ humanarchitecture/vol5/iss3/36. Accessed 10 Aug. 2014.

Boatright, Michael D. "Graphic Journeys: Graphic Novels' Representations of Immigrant Experiences.” Journal of Adolescent and Adult Literacy, vol 53, no.6, Mar. 2010, pp. 468-76. JSTOR, https://www.jstor.org/ stable/25614591. Accessed 23 May 2014.

Cadden, Mike. "But you are still a Monkey: American Born Chinese and Racial Self-Acceptance." The Looking Glass: New Perspectives on Children's Literature, vol. 17, no. 2, Mar/Apr 2014, www.lib. latrobe.edu.au/ojs/index.php/tlg/article/view/477/427. Accessed 9 Nov. 2017 Césaire, Aimé Fernand David. Discourse on Colonialism. 1955. Translated by Joan Pinkham, Monthly Review P., 1972, abahlali.org/files/_ Discourse_on_Colonialism.pdf. Accessed 17 Aug. 2014.

-----. "An Interview with Aimé Césaire." by René Depestre, Discourse on Colonialism, Monthly Review P., 1972, www.rlwclarke.net/theory/ SourcesPrimary/ CesaireDiscourseonColonialism.pdf. Accessed 17 Aug. 2014.

Chaney, Michael A. "Animal Subjects of the Graphic Novel." College

Literature, vol. 38, no. 3, Summer 2011, pp. 129-49. Project Muse, doi.org/10.1353/lit.2011.0024. Accessed 10 Jan. 2014. 
Davis, Rocio G. "American Born Chinese: Challenging the Stereotype." Graphic Subjects: Critical Essays on Autobiography and Graphic Novels, edited by Michael A. Chaney, Wisconsin UP, 2011, pp. 279-81.

-----. "Childhood and Ethnic Visibility in Gene Yang's American Born Chinese." Prose Studies: History, Theory, Criticism, vol. 35, no.1, Apr. 2013, pp. 7-15, dx.doi.org/10.1080/01440357.2013.781341. Accessed 26 Apr. 2014.

Doughty, Jonathan. "More than Meets the 'I': Chinese Transnationality in Gene Luen Yang's American Born Chinese." Asian American Literature: Discourse and Pedagogies, vol. 1, no.1, Apr 2010, San Jose State U, 2010, pp. 54-60.

Du Bois, W.E.B. The Souls of Black Folk. 1903. Pennsylvania State U, 2006. The Electronic Classic Series, www2.hn.psu.edu/faculty/jmanis/.../ duboissoulsblackfolk6x9.pdf . Accessed 15 Aug. 2014.

Duncan, Ralph Randolph. Panel Analysis: A Critical Method for Analyzing the Rhetoric of Comic Book Form. Dissertation, Louisiana State U and Agricultural and Mechanical College, 1990. UMI, 1990. Proquest Dissertations and Theses, search.proquest.com/docview/ 303876998? accountid=178282. Accessed 15 June 2014.

Fanon, Frantz. Black Skin, White Masks. Translated by Charles Lam Markmann, Pluto, 1986.

-----. The Wretched of the Earth. Translated by Richard Philcox, Grove, 2004.

Forceville, Charles J. and Thijs Renckens. "The Good is Light and Bad is Dark Metaphor in Feature Films." Metaphor and the Social World, vol.3, no.2, 2013, pp. 160-79. Ebscohost, DOI 10.1075/msw.3.2.03. Accessed 1 Sept. 2014.

Forceville, Charles, et al. "Balloonics: The Visuals of Balloons in Comics." The Rise and Reason of Comics and Graphic Literature: Critical Essays on the Form, edited by Joyce Goggin and Dan Hassler-Forest, McFarland, 2010, pp. 56-73.

Freud, Sigmund. The Ego and the Id. Translated by Joan Riviere, Hogarth P, 1926. Internet Archive Python Library, archive.org/details/ in.ernet.dli.2015.218607. Accessed 11 Nov. 2017.

-----. The Uncanny. Translated by David Mclintock, Penguin, 2003, pp. 123 62, www.english.upenn.edu/ cavitch/pdf-library/Freud_Uncanny.pdf. Accessed 23 May 2014.

Fu, Binbin. Review of American Born Chinese, by Gene Luen Yang. Coloring America: Multi-Ethinc Engagements with Graphic Narrative, spec. issue of Melus, Vol. 32, no.3, Fall 2007, pp. 274-76. JSTOR, www.jstor.org/stable/30029808. Accessed 12 July 2014. 
Gardner, Jared. "Same Difference: Graphic Alterity in the Work of Gene Luen Yang, Adrian Tomine, and Derek Kirk." Multicultural Comics: From Zap to Blue Beetle, edited by Frederick Luis Aldama, Texas UP, 2010, pp.132-47.

Gomes, Cheryl and James Bucky Carter. "Navigating through Social Norms, Negotiating Place: How 'American Born Chinese' Motivates Struggling Learners." The English Journal, vol, 100, no. 2, Nov. 2010, pp. 68-76. Jstor, www.jstor.org/stable/25790038.Accessed 26 Mar. 2014.

Groensteen, Thierry. Comics and Narration, Mississippi UP, 2013.

Hammond, Heidi. "Graphic Novels and Multi-modal Literacy: A High School Study with American Born Chinese." Bookbird: A Journal of International Children's Literature, vol. 50, no. 4, 2012, pp. 22-32. Project Muse, muse.jhu.edu/article/487148. Accessed 25 Mar. 2014.

Henderson, Randy. "William Hung: A Cruel, Racist Joke for 'American Idol'." The Seattle Times, 24 Apr. 2004, community.seattletimes. nwsource.com/archive/?date $=20040424 \&$ slug=nexthung25. Accessed 24 July 2014.

Hook, Derek. Fanon and the Psychoanalysis of Racism. LSE Research Online, 2007, pp. 114-37, eprints.lse.ac.uk/2567/1/Fanonandthepscyho. pdf. Accessed 12 July 2014.

Kim, Jean. "Asian American Racial Identity Development Theory." New Perspectives on Racial Identity Development: Integrating Emerging Frameworks, edited by Charmaine Wijeeyesinghe and Bailey W. Jackson, 2nd ed., NYU Press, 2012, pp. 138-60.

Kukkonen, Karin. Studying Comics and Graphic Novels. Wiley, 2013.

Ma, Sheng-Mei. "Gene Luen Yang's Graphic Bi-Bye to China/Town." Sinophone-Anglophone Cultural Duet. Palgrave Macmillan, 2017, pp. 10322. DOI 10.1007/978-3-319-58033-3_7. Accessed 6 Nov. 2017

Marcia, James E. "Development and Validation of Ego-Identity Status." Journal of Personality and Social Psychology, vol. 3, no. 5, 1966, pp. 551-58, pdfs.semanticscholar.org/f145/f3fbada1eb7a01052255f58609430166 9287.pdf. Accessed 18 July 2014.

McCloud, Scott. Making Comics: Storytelling Secrets of Comics, Magna, and Graphic Novels. Harper, 2006.

Oh, Stella. "Laughter against Laughter: Interrupting Racial and Gendered Stereotypes in Gene Luen Yang's American Born Chinese." Journal of Graphic Novels and Comics, vol. 8, no.1, Feb. 2017, pp-20-32, Taylor \& Francis, dx.doi.org.mplbci.ekb.eg/10.1080/21504857.2016.1233897. Accessed 10 Nov. 2017.

-----. Understanding Comics. Kitchen Sink, Harper Collins, 1993. 
Painter, Clare, et al. Reading Visual Narratives: Image Analysis in Children's Picture Books. Equinox, 2012.

Phinney, Jean S. "Ethnic Identity in Adolescents and Adults: Review of Research." Psychological Bulletin, vol. 108, no. 3, Nov. 1990, pp. 499-514. www.researchgate.net/profile/Jean_Phinney/publication/20886312_

Ethnic_Identity_in_Adolescents_and_Adults_Review_of_Research/links/0f cfd5100589bece91000000/Ethnic-Identity-in-Adolescents-and-Adults-

Review-of-Research.pdf. Accessed 11 May 2014.

----. "Stages of Ethnic Identity Development in Minority Group Adolescents."

The Journal of Early Adolescence, vol. 9, no.1-2, May 1989, pp. 34-49. Sage Publications, doi.org/10.1177/0272431689091004. Accessed 15 Apr. 2014. Phinney, Jean S. and Doreen A. Rosenthal. "Ethnic Identity in Adolescence: Process, Context, and Outcome." Adolescent Identity Formation. Edited by Gerald R. Adams, et. al., Sage, 1992, pp. 145-72. Advances in Adolescent Development 4.

Rank, Otto and Harry Tucker. Double: A Psychoanalytic Study. U of North Carolina P, 1971.

Said, Edward. "Introduction". Orientalism. Pantheon, 1978, pp. 1-28.

Schieble, Melissa. "A Case for Interruption in the Virtual English Classroom with the Graphic Novel American Born Chinese." Australian Journal of Language and Literacy, vol. 34, no. 2, 2011, pp. 202-18.

Schumann, Claudia. "Graphic Contaminations: Cosmopolitics of the 'I' in American Born Chinese and Persepolis." Studier i Paedagogik Filosofi, vol. 4, no.2, 2015, pp. 38-53, tidsskrift.dk/index.php/spf/article/view/ 22423/20408. Accessed 11 Nov. 2017.

Sarigianides, S. T. "Coerced Loss and Ambivalent Preservation": Racial Melancholia in American Born Chinese. Educational Theory, vol.67, no.1, Feb. 2017, pp. 37-49, doi:10.1111/edth.12224. Accessed 12 Nov. 2017.

Smith, Elsie J. "Ethnic Identity Development: Toward the Development of a Theory within the Context of a Majority, Minority Status." Journal of Counseling and Development, vol. 70, Sept./Oct. 1991, pp.181-88.

Smith, Philip. "Postmodern Chinoiserie in Gene Luen Yang's American Born Chinese." Literature Compass, vol.11, no.1, 2014, pp. 1-14. Wiley Online Lib, doi.org/10.1111/lic3.12115. Accessed 20 July 2016.

Song, Min Hyoung. "How Good it is to be a Monkey: Comics, Racial Formation, and American Born Chinese." Mosaic (Winnipeg), vol.43, no.1, Mar. 2010, pp. 73-92. Jstor, www.jstor.org/stable/44030639. Accessed 12 Apr. 2015.

Sue, Derald Wing and David Sue. Counseling the Culturally Diverse: Theory and Practice. $4^{\text {th }}$ ed., John Wiley \& Sons, 2003. 
"Understanding Formal Analysis: Elements of Art." The J. Paul Getty Museum. The J. Paul Getty Trust, 2011, www.getty.edu/education/ teachers/building_lessons/elements_art.pdf. Accessed 15 May 2014.

Wang, Jiahong. "Between Realism and Genre Fiction: American Born Chinese and Strange Fruit." The Midwest Quarterly, 1 Jan. 2017, pp. 220-41.

Yang, Gene Luen. American Born Chinese. First Second, 2006.

-----. "American Born Chinese." Interview by Rick Margolis. School Library Journal, vol. 52, no. 9, Sept. 2006, p. 41.

-----. "Gene Luen Yang: American Born Chinese." Interview by Gillian Engberg. Booklist, vol.103, no.13, 1 Mar. 2007, p. 75.

-----. "Talking to Gene Yang; 'American Born Chinese' Creator is coming to Buffalo." Interview by Heeseung Kim. Buffalo News, 2 July 2008, p. N6. LexisNexis, www.lexisnexis.com.library.aucegypt.edu:2048/Hottopics/ lnacademic/?verb=sr\&csi=8399\&sr=HLEAD(Talking\%20to\%20Gene $\% 20$ Yang)\%20and\%20date\%20is\%202008. Accessed 14 Apr. 2014.

Zivkovic, Milica. "The Double as the Unseen of Culture: Toward a Definition of Doppelganger." The Scientific Journal of Facta Universitatis, vol. 2, no. 7, 2000, pp. 121-28. Linguistics and Lit, facta.junis.ni.ac.rs/ lal/lal2000/lal2000-05.pdf. Accessed 14 Apr. 2014. 